\title{
GFAP as a marker of reactive astrocytes in the mice brain following hemorrhagic stroke and HSV-I
}

\author{
A. V. Gumenyuk ${ }^{1}$, S. L. Rybalko², S. I. Savosko ${ }^{1}$, M. M. Guzyk ${ }^{3}$, \\ A. O. Tykhomyrov ${ }^{3}$, A. A. Ryzha ${ }^{4}$, Yu. B. Chaikovsky ${ }^{1}$ \\ ${ }^{1}$ Bogomolets National Medical University \\ 13, Shevchenko Blvd., Kyiv, Ukraine, 01601 \\ ${ }^{2}$ Gromashevsky L. V. Institute of Epidemiology and Infection Diseases, NAMS of Ukraine \\ 5, Amosova Str., Kyiv, Ukraine, 03038 \\ ${ }^{3}$ Palladin Institute of Biochemistry, NAS of Ukraine \\ 9, Leontovycha Str., Kyiv, Ukraine, 01601 \\ ${ }^{4}$ Educational and Scientific Center "Institute of Biology and medicine", Taras Shevchenko National University of Kyiv \\ 64/13, Volodymyrska Str., Kyiv, Ukraine, 01601 \\ yuri.chaikovsky@nтu.ua
}

\begin{abstract}
Aim. To investigate reactive changes of GFAP-positive astrocytes as a marker of brain response following hemorrhagic stroke and HSV-I. Methods. The experiments were performed on 110 Balb/c mice weighing 18-20 g. The animals were infected with HSV type I, on 30 day hemorrhagic stroke was simulated and changes in astrocytes were determined by immunohistochemistry. Gliosis was confirmed by changes in density and arborization of GFAP-positive astrocytes. Results. The results of immunohistochemical studies confirmed increased density of GFAP-positive astrocytes in the hippocampus of mice infected with HSV type I as well as the sharp increase in the density and hypertrophy of GFAP-positive astrocytes following stroke simulation in infected animals. Conclusions. The experiment has provided new evidence about the location and level of astrocytic gliosis following a stroke and herpes infection. GFAP can be studied as a marker of HSV type I reactivation against stroke.
\end{abstract}

Keyw or d s: GFAP, astrocytes, HSV type I, stroke

\section{Introduction}

Glial fibrillary acidic protein (GFAP) is a basic intermediate filament of astrocytes [1]. In the intact brain astrocytes carry out such functions as trophic, formation of the blood-brain barrier and neurotransmitters metabolism. The GFAP expression in the intact astrocytes takes place constantly. In addition GFAP-knockout mice usually suffer for multiple degenerative

(C) 2017 A. V. Gumenyuk et al.; Published by the Institute of Molecular Biology and Genetics, NAS of Ukraine on behalf of Biopolymers and Cell. This is an Open Access article distributed under the terms of the Creative Commons Attribution License (http://creativecommons.org/licenses/by/4.0/), which permits unrestricted reuse, distribution, and reproduction in any medium, provided the original work is properly cited 
processes, for example, abnormal myelination of the brain's white matter and violation of the blood-brain barrier [2].

As a consequences of brain damage the astrocytes hypertrophy, increase in appendages length, raise of GFAP expression and density of GFAP-positive cells occur into the lesion site. These morphological and biochemical changes were called an astrocytic gliosis, or astrogliosis [3]. The astrogliosis manifests through the glial scars formation which results in separation the affected area from the intact brain tissue. Although the astrocytic gliosis is considered as structural manifestation of nerve system pathological changes there are conclusive evidence that gliosis is typical protective reaction of the central nerve system which forms against the different types of damage. The astrocytes restrict the foci of inflammation and necrosis, recover the blood-brain barrier and synthesize the cytokines [4]. The last research indicated that astrocytes take part in the implementation of proinflammatory immune reactions as well as in the anti-inflammatory protective function. All the changes develop as proliferation and migration of astrocytes while on the cytology level as raise of GFAP expression and increase in appendages length of GFAP-positive astrocytes. Pay attention to the changes of GFAP expression we can forecast the nature of brain structural changes. In this case the decrease of GRFAP-positive cells should be the manifestation of necrosis or apoptosis of gliocytes while the increase of GFAP-positive cells shows the reactive changes, regeneration or metabolic restructuring [5].

Exploring the reactive changes in the brain by GFAP expression allows us to learn the patterns of brain injury and recovery. One of the current interest is a study of the cerebrovascular accident and inflammation because the stroke isn't limited by the ischemic brain damage but can be described with development of inflammation and neurodegeneration [6, 7]. During a long time neurodegenerative changes were examined as focal or diffuse neuronal death. Nowadays we don't divide the neural and glial pathology but evaluate it as a systemic histopathological process [8].

In the previous study we have reported the dependence of neurodegeneration in mice's brains on human simplex virus (HSV-1) reactivation after stroke modeling. In the hippocampus of infected animals the number of dead neurons correlated with the quantitative indicators HSV-1 in the brain samples in vitro (PCR, IFA, cell culture Vero). Nevertheless the astrocytes role and methods of reactive changes determining didn't investigate. In this work we have determined the gliosis by GFAP-positive astrocytes level in the brain of HSV-1-infected mice.

The goal of our work was to investigate the GFAP-positive astrocytes changes as the manifestation of their reactive changes in response to brain damage with hemorrhagic stroke and HSV-1-infection.

\section{Table 1. Groups of animals}

\begin{tabular}{|l|c|}
\hline \multicolumn{1}{|c|}{ Group } & Quantity \\
\hline Group 1 - HSV-1 infected mice & 15 \\
Group 2 - mice with hemorrhagic stroke & 15 \\
Group 3 - HSV-1 infected mice with & 40 \\
hemorrhagic stroke & \\
Control group 1 - intact mice & 10 \\
Control group 2 - control to the group 1 & 10 \\
Control group 3 - control to the group 2 & 10 \\
Control group 4 - control to the group 3 & 10 \\
\hline
\end{tabular}




\section{Materials and Methods}

The experiments were held on the 110 white mice Balb/c with a weight of 18-20 gm. All animals were divided into 7 groups (Table 1).

The technique of infecting (group 1) was based on the epidural $0,03 \mathrm{ml}$ of virus-containing material $\left(\mathrm{LD}_{50}\right)$ injection into the orphan site. We used the lyophilized HSV-1 (strain VC). This model renders a meningoencephalitis in $100 \%$. The symptoms of infectious process are usually noted on the $5^{\text {th }}-6^{\text {th }}$ day, peak on the $13^{\text {th }}-14^{\text {th }}$ day, after that decrease and animals recover. As a result the HSV-1 infection turns to the latent form.

The intracerebral hemorrhage (ICH) (group 2) was accomplished by $0,15-0,2 \mathrm{ml}$ of autoblood injection into the brain's right hemisphere $(\mathrm{L}=1,5 ; \mathrm{H}=3,0 ; \mathrm{AP}=-1,0 \mathrm{~mm}$ from Bregma) (Fig. 1). The manipulation was run due to the stereotactic atlas [11]. According to this model the ICH and neurological disorders formed in animals. The hemorrhage localized in the capsula interna, CI. On the day 30 after HSV-infection animals from group 3

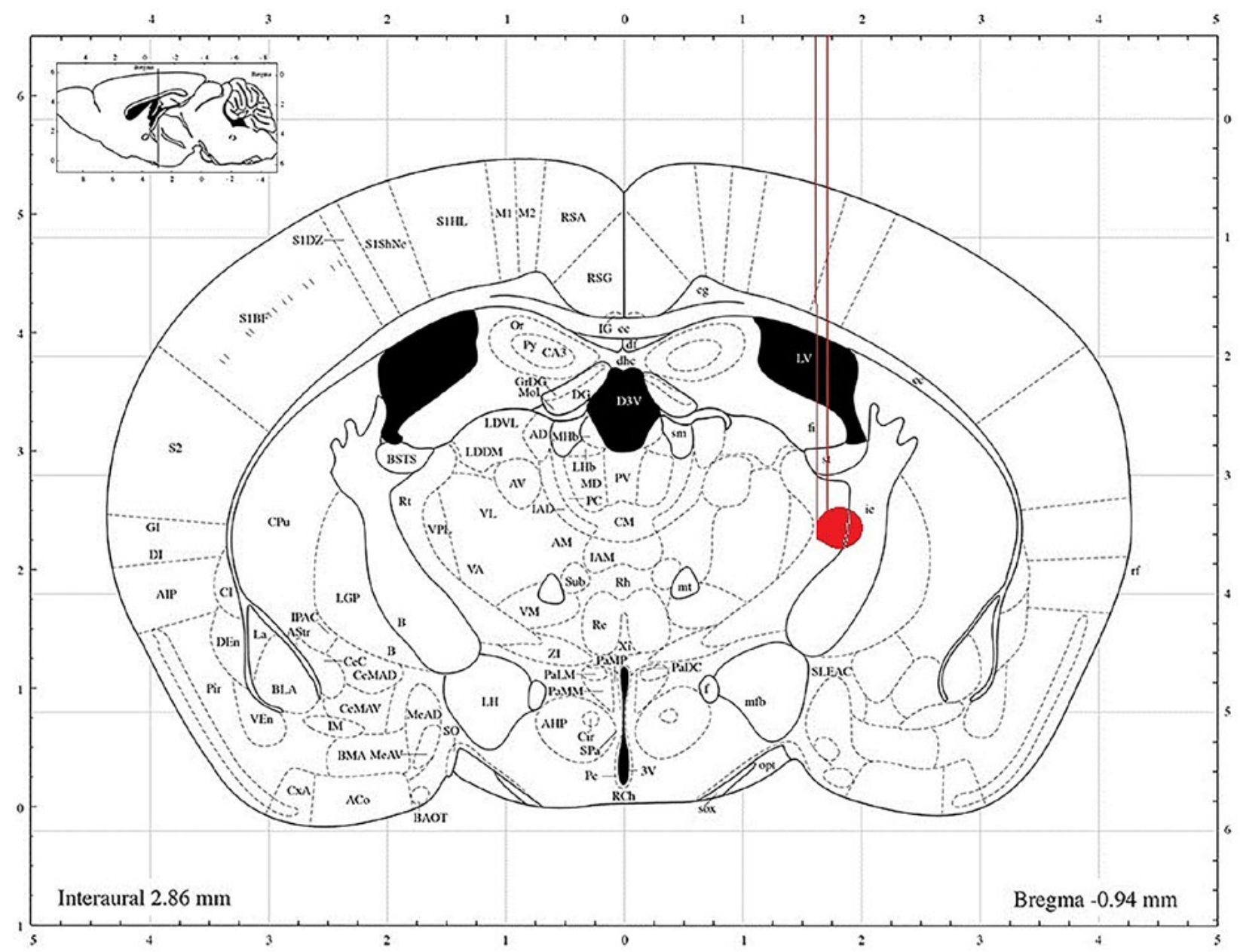

Fig. 1. There is a scheme of the autoblood injection into the mouse brain. The right capsula interna site is pointed. 
(weakness, sedentary, decrease in appetite) were modeled the ICH.

The control animals were divided into 4 groups for 10 mice. Control group 1 was the intact animals. Control group 2 was the animals injected with the $0,03 \mathrm{ml}$ of saline into the orphan site. Control group 3 was the mice operated with a needle into the brain's right hemisphere $(\mathrm{L}=1,5 ; \mathrm{H}=3,0 ; \mathrm{AP}=-1,0 \mathrm{~mm}$ from Bregma) without autoblood injection. Control group 4 was the mice injected with the $0,03 \mathrm{ml}$ of saline into the orphan site and then operated with a needle into the brain's right hemisphere $(\mathrm{L}=1,5 ; \mathrm{H}=3,0 ; \mathrm{AP}=-1,0 \mathrm{~mm}$ from Bregma) without autoblood injection on the day 30 after HSV-infection.

The animals were removed from the experiment on the day 40 in the group 1 and on the day 10 after stroke modeling. For immunohistochemical analysis the mice' brains were fixed in the paraformaldehyde solution, washed with the saline, conducted in the ethyl alcohol increasing concentrations and perfused in the Leica Surgipath Paraplast Regular. The frontal 6 microns thick sections were gotten using a Thermo Microm HM 360 microtome.

These sections were deparafinized in the xylene and ethyl alcohol increasing concentrations, air-dried and washed with the buffered saline (PBS). Then the sections were blocked into the $3 \%$ bovine serum albumin solution (BSA) in the PBS with $0,05 \%$ Triton X-100 (PBST) during 60 minutes at room temperature. After that the sections were incubated with the antibodies against GFAP (rabbit antiGFAP antibodies, sc-9065, Santa Cruz Biotechnology, USA) in the 1:200 dilution in PBST during 18 hours at $+4{ }^{\circ} \mathrm{C}$. Anti-GFAP antibody was a kind gift of Prof. V.S.
Nedzvetsky (Dnipro National University, Ukraine). The sections were subsequently washed for 3 times and then incubated with the secondary antibodies conjugated with a fluorescein isothiocyanate (FITC) in the 1:500 dilution in PBST during 60 minutes at room temperature. In order to visualize the cells' nuclei the sections were washed again and treated with a Hoechst-33342 fluorescent dye $(1 \mathrm{mcg} / \mathrm{ml})$. The results of the immunofluorescent staining were gotten with a Carl Zeiss LSM 510 microscope (Carl Zeiss, Germany) and processed in the Zeiss ZEN software. In addition we have used the toluidine blue staining to identify the cells composition and the inflammation and neurodegeneration foci in the all brains samples.

For the quantitative assessment of the GFAPpositive astrocytes changes we have carried out a morphometric examination. The number of astrocytes in the $0,25 \mathrm{~mm}$ of the test area and cells perimeter were measured. The perimeter was determined using the contours of the visible GFAP-positive binding profile (body and appendages of the astrocytes).

All the experimental procedures comply with the international ethical standards such as "Regulations on the animal use of in research biomedical research", "European Convention for the protection of vertebrate animals used for experimental and other scientific purposes", "Guide for the Care and Use of Laboratory Animals" and the standards of Commission on bioethics of Bogomolets National Medical University.

\section{Results and Discussion}

The results of mice' brains immunohistochemical analysis detected a significant increase of 
specific antibodies to GFAP binding in the HSV-infected animals. In the hemorrhagic stroke and virus infection conditions a synthesis level was more expressed (Fig. 2).

It should be noted that we have not discovered the significant difference between the astrocytes staining intensity of control groups. In the groups 1-4 the specific immunostaining was found only round the nuclei while in the pathology conditions the dense GFAP-positive binding was found in the cells' bodies as well as in the numerous appendages what indicated the astrocytes hypertrophy. We often marked the specific antibodies to GFAP binding around the microvessels as the astrocytes appendages located around the hemocapillaries. These findings make us sure about reactive gliosis manifestation in the infection condition.
The topography and glial reaction analysis showed the dominant development of local astrogliosis in the perifocal zone (CA1 and CA3 hippocampus sites) or diffuse gliosis in all hippocampus sites, corpus callosum and deep layers of ipsilateral hemisphere neocortex.

The progressive gliosis was detected through the quantitative density of GFAPpositive astrocytes determination in the ipsilateral cerebral cortex and CA1 hippocampus site (Fig 3, 4). We have not discovered the statistically significant difference between the astrocytes quantitative indicators in the control groups. Therefore we used data from the intact mice to make the figures and data from all control groups of animals for comparison. The significant density increase of astrocytes in the CA1 hippocampus site was found in the
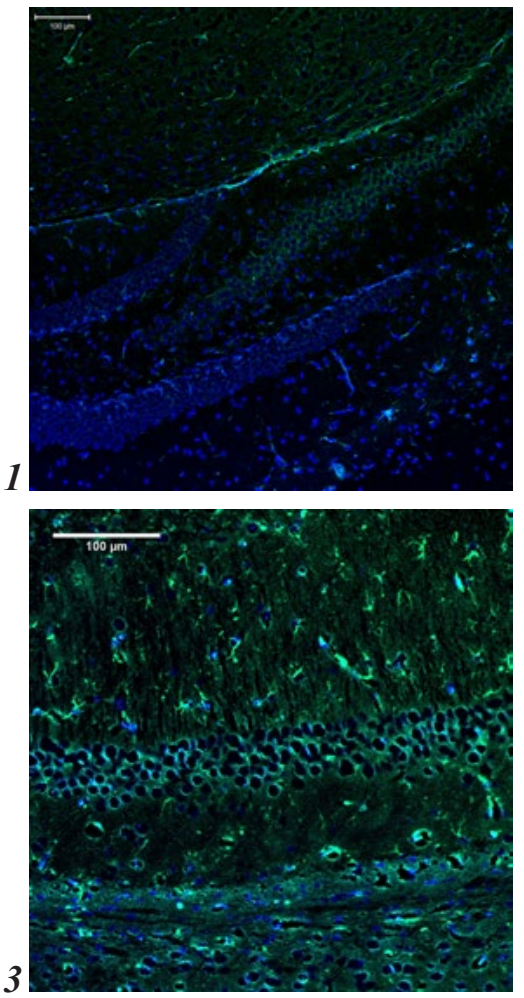
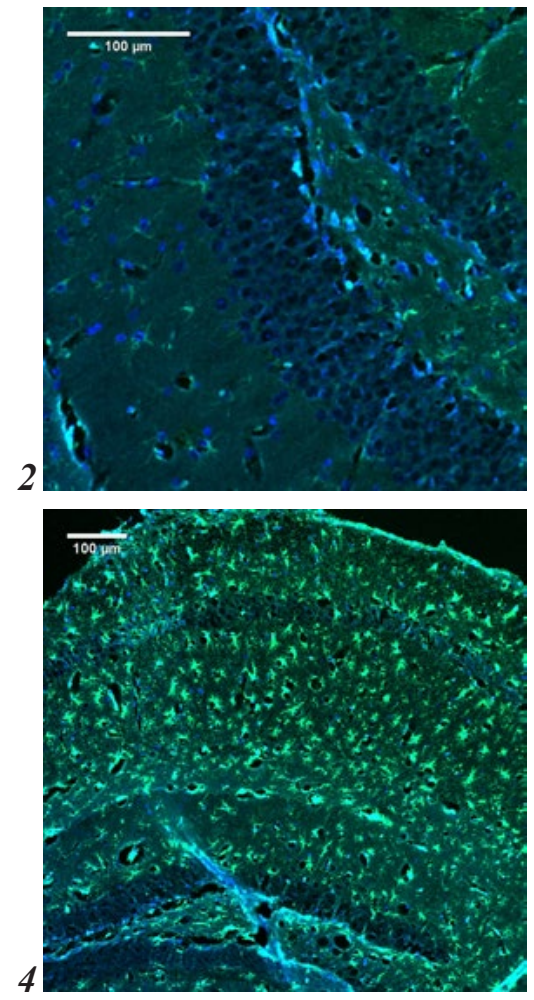

Fig. 2. The immunohistochemical analysis of mice' brains frontal sections in the hemorrhagic stroke, HSV-1 and hemorrhagic stroke with HSV-infection conditions. Specific antibodies to GFAP binding; the nuclei colored with Hoechst-33342 fluorescent dye, confocal microscopy. 1 - CA1 hippocampus site of the intact mice; 2 - CA1 hippocampus site of the mice with hemorrhagic stroke; 3-CA1 hippocampus site of the HSV-infected mice; 4-CA1 hippocampus site of the HSV-infected mice with hemorrhagic stroke. 


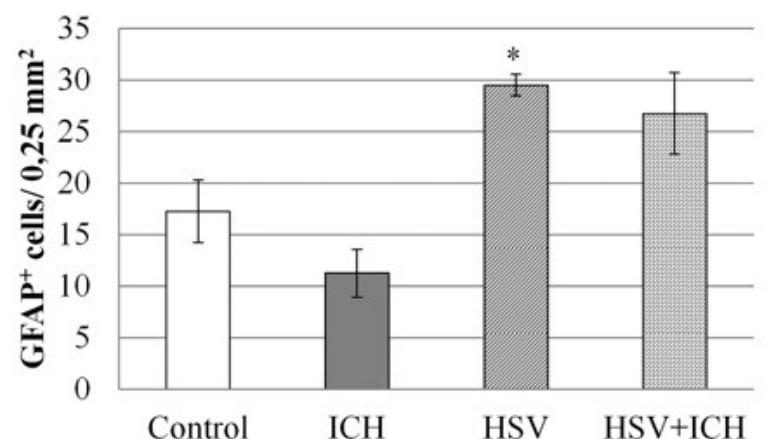

Fig. 3. There is GFAP-positive astrocytes density in the cortex. Note: ${ }^{*}$ - significantly compared to the control $(\mathrm{p}<0,05)$.

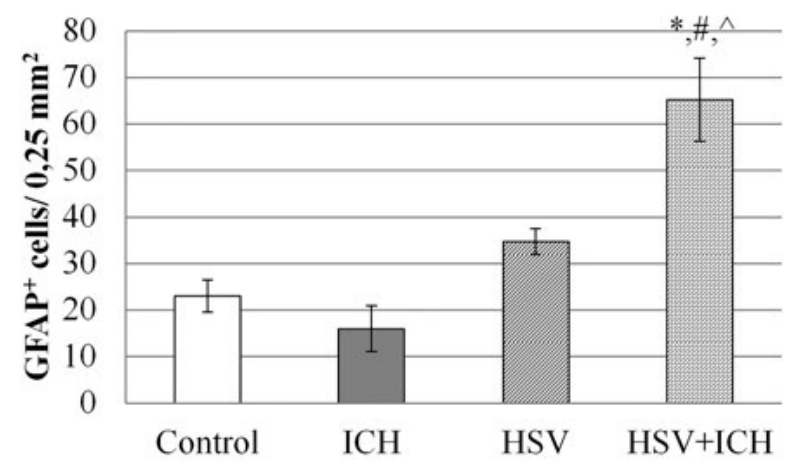

Fig. 4. There is GFAP-positive astrocytes density in the CA1 hippocampus site of ipsilateral hemisphere. Note: * - significantly compared to the control $(\mathrm{p}<0,05)$; \# significantly compared to the group $1(\mathrm{p}<0,05) \dot{ }^{\wedge}-$ significantly compared to the group $2(\mathrm{p}<0,05)$.

group 3. This index after stroke modeling statistically significant rose approximately 2,8 times.

There are results of the morphometric analysis on the Fig. 5 and 6 which show the statistically significant increase of GFAP-positive astrocytes perimeter (with the appendages considered) in the HSV-infected animals (groups 1, 3)

The variability of astrogliosis development may be connected with the infectious process

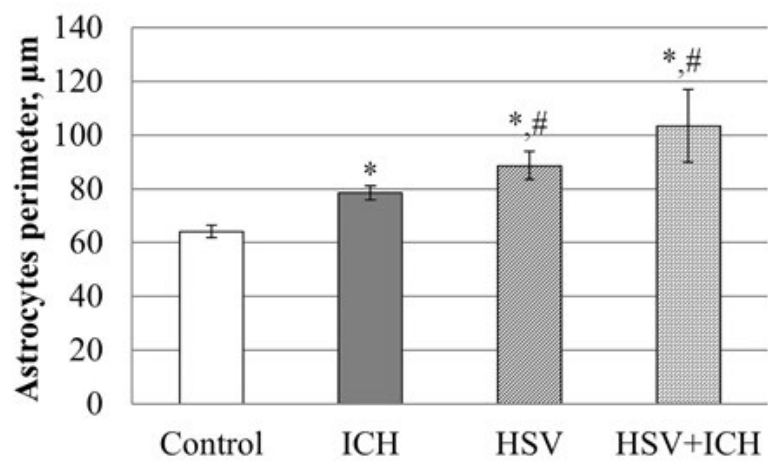

Fig. 5. There is GFAP-positive astrocytes perimeter in the cortex. Note: * - significantly compared to the control $(\mathrm{p}<0,05) ; \#-$ significantly compared to the group 1 $(\mathrm{p}<0,05)$.

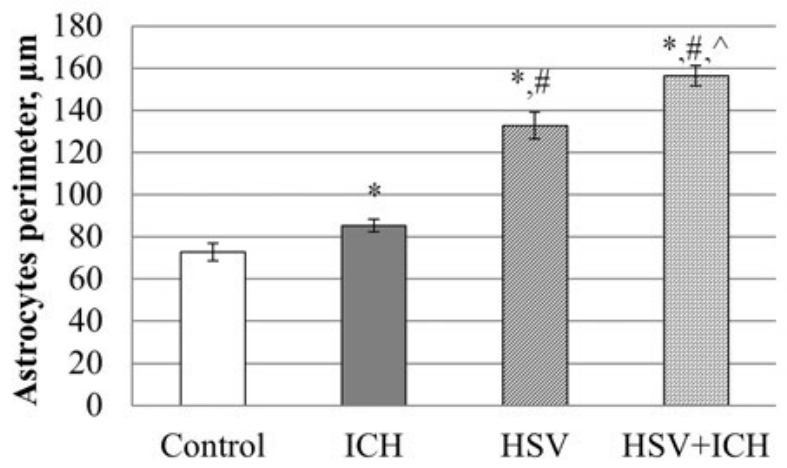

Fig. 6. There is GFAP-positive astrocytes perimeter in the CA1 hippocampus site of ipsilateral hemisphere. Note: * - significantly compared to the control $(\mathrm{p}<0,05)$; $\#-$ significantly compared to the group $1(\mathrm{p}<0,05) ;{ }^{\wedge}-$ significantly compared to the group $2(\mathrm{p}<0,05)$.

level and brain ischemia size. But a brain edema as the main histostructural agent of brain damage progresses into the hemorrhage site as well as into the contralateral hemisphere. This process mainly occurs through the corpus callosum. However the astrocytes reactive changes were only discovered in the brain's ipsilateral hemisphere what represents the astrocytes answer to the herpetic neuroinfection.

As we know, GFAP is a specific protein of astrocytes' intermediate filaments. This protein 
provides the structure and sturdiness of intact astrocytes' cytoskeleton but in the brain injury condition the GFAP expression can increase abruptly. This index can vary dramatically in some pathological conditions, for example, cerebral trauma [12], stroke [13], Alzheimer's disease [14] and Parkinson's disease [15]. The synthesis of GFAP is activated by numerous growth factors such as ciliary neurotrophic factor (CNTF) [16], fibroblast growth factor (FGF), transforming growth factor $\beta$ (TGF- $\beta$ ) [17] and interleukins [18].

The relationship between astrocytes reactions and neuroinfection was performed only in a few studies. Nowadays we have not any data or methodical approaches (cytological, histological) for primary herpetic infection localization detection in the CNS. It is considered that the latent infection localizes into the ganglions' neurons but at the same time the virus was detected in the brain's stem [19]. The cortex damage was discovered after virus injection into the facial nerve [20]. In these studies the neurons apoptosis is examined as the main path of neurodegeneration in HSV-infection condition. Nevertheless, the vascular and glial factors are focused on too. In particular the astrocytes and macrophages activation into the brain in herpetic encephalitis condition and gliosis development were showed through the immunocytochemical method [21].

In our study an increase in the number of GFAP-positive astrocytes appendages around the blood vessels may be determined by microvessels participation in the inflammatory process. We can assume that the astrocytes take part in the blood-brain barrier recover as well as in the intercellular interaction with immunocompetent cells.
In this way the data we have received through our investigation point out the role of the GFAPpositive astrocytes in the herpetic infection development and reactivation after stroke. The further research about the glial cells participation in the neurodegeneration process is important in order to understand the general character of brain damage development.

\section{Conclusions}

In the HSV-1-infection condition the increase of GFAP-positive astrocytes takes place (into the hippocampus mainly) as well as after stroke modeling but the last one is also characterized by increased GFAP expression. The perifocal localization of astrocytic gliosis explains the brain structural changes after stroke and virus reactivation. GFAP is considered to be a marker for HSV-reactivation in the stroke condition.

\section{REFERENCES}

1. Yang $Z$, Wang $K K W$. Glial Fibrillary acidic protein: From intermediate filament assembly and gliosis to neurobiomarker. Trends in neurosciences. 2015; 38 (6): 364-74.

2. Liedtke W, Edelmann W, Bieri PL, Chiu FC, Cowan $N J$, Kucherlapati R, Raine CS. GFAP is necessary for the integrity of CNS white matter architecture and long-term maintenance of myelination. Neuron. 1996; 17 (4): 607-15.

3. Smajlović $D$. Strokes in young adults: epidemiology and prevention. Vascular Health and Risk Management. 2015; 11: 157-64.

4. Korhonen P, Kanninen KM, Lehtonen $\check{S}$, Lemarchant S, Puttonen KA, Oksanen M, Dhungana H, Loppi S, Pollari E, Wojciechowski S, Kidin I, García-Berrocoso T, Giralt D, Montaner J, Koistinaho J, Malm T. Immunomodulation by interleukin-33 is protective in stroke through modulation of inflammation. Brain Behav Immun. 2015; 49: 322-36. 
5. Burda JE, Bernstein AM, Sofroniew MV. Astrocyte roles in traumatic brain injury. Experimental neurology. 2016; 275 (03): 305-15.

6. Sirko S, Irmler M, Gascón S, Bek S, Schneider $S$, Dimou L, Obermann J, De Souza Paiva D, Poirier F, Beckers J, Hauck SM, Barde Y-A., Götzcorresponding M. Astrocyte reactivity after brain injury - : The role of galectins 1 and 3. Glia. 2015; 63 (12): 2340-61.

7. Anderson MA, Burda JE, Ren Y, Ao Y, O'Shea TM, Kawaguchi R, Coppola G, Khakh BS, Deming TJ, Sofroniew MV. Astrocyte scar formation aids CNS axon regeneration. Nature. 2016; 532 (7598): 195200.

8. Sofroniew $M V$. Astrocyte barriers to neurotoxic inflammation. Nature reviews Neuroscience. 2015; 16 (5): 249-63.

9. Gumenyuk AV, Motorna NV, Rybalko SL, Savosko SI, Sokurenko LM, Chaikovsky YuB. Mutual influence of herpes virus infection activation and cerebral circulation impairment on the state of brain cells. Biopolym. Cell. 2016; 32 (2): 126-30.

10. Gumenyuk A, Motorna N, Rybalko S, Savosko S, Sokurenko L, Starosyla D, Porva Yu, Chaikovsky Yu. Development of herpetic infection associated with stroke and its correction with acyclovir. Curr Issues Pharm Med Sci. 2017; 30 (1): 20-3.

11. Paxinos $G$, Franklin KBJ. The mouse brain in stereotaxic coordinates: hard cover edition. Access Online via Elsevier. 2001.

12. Pelinka LE, Kroepfl A, Schmidhammer R, Krenn M, Buchinger W, Redl H, Raabe A. Glial fibrillary acidic protein in serum after traumatic brain injury and multiple trauma. J Trauma. 2004; 57 (5): 1006-12.

13. Wunderlich MT, Wallesch CW, Goertler M. Release of glial fibrillary acidic protein is related to the neurovascular status in acute ischemic stroke. Eur J Neurol. 2006; 13 (10): 1118-23.

14. Kamphuis W, Middeldorp J, Kooijman L, Sluijs JA, Kooi EJ, Moeton M, Freriks M, Mizee MR, Hol EM. Glial fibrillary acidic protein isoform expression in plaque related astrogliosis in Alzheimer's disease. Neurobiol Aging. 2014; 35 (3): 492-510.

15. Su W, Chen HB, Li SH, Wu DY. Correlational study of the serum levels of the glial fibrillary acidic protein and neurofilament proteins in Parkinson's disease patients. Clin Neurol Neurosurg. 2012; 114 (4): $372-5$.

16. Seidel JL, Faideau M, Aiba I, Pannasch U, Escartin C, Rouach N, Bonvento $G$, Shuttleworth $C W$. Ciliary neurotrophic factor (CNTF) activation of astrocytes decreases spreading depolarization susceptibility and increases potassium clearance. Glia. 2015; 63 (1): 91-103.

17. Yu Z, Yu P, Chen H, Geller HM. Targeted inhibition of $\mathrm{KCa} 3.1$ attenuates TGF- $\beta$-induced reactive astrogliosis through the Smad2/3 signaling pathway. J Neurochem. 2014; 130 (1): 41-9.

18. Gomes FC, Paulin D, Moura Neto V. Glial fibrillary acidic protein (GFAP): modulation by growth factors and its implication in astrocyte differentiation. Braz J Med Biol Res. 1999; 32 (5): 619-31.

19. Watanabe D, Honda T, Nishio K, Tomita Y, Sugiura $Y$, Nishiyama Y. Corneal infection of herpes simplex virus type 2-induced neuronal apoptosis in the brain stem of mice with expression of tumor suppressor gene (p53) and transcription factors. Acta Neuropathol. 2000; 100: 647-53.

20. Kabakus N, Alpay HC, Godekmerdan A, Gok U, Akpolat $N$. Peripheral facial paralysis and apoptosis induced by herpes simplex type I virus: A rat study. Turkish Journal of Medical Sciences. 2005; 35 (6): 365-70.

21. Schutz PW, Fauth CT, Al-Rawahi GN, Pugash D, White VA, Stockler S, Dunham CP. Granulomatous Herpes Simplex Encephalitis in an Infant With Multicystic Encephalopathy: A Distinct Clinicopathologic Entity? Pediatr Neurol. 2013; 50 (4): 392-96.

GFAP як показник реактивних змін астроцитів у мозку мишей 3 геморагічним інсультом та ВПГ-І

\author{
А. В. Гуменюк, С. Л. Рибалко, С. І. Савосько, \\ М. М. Гузик, А. О. Тихомиров, А. О. Рижа, \\ Ю. Б. Чайковський
}

Мета. Дослідити зміни GFAP-позитивних астроцитів як прояв їх реактивних змін у відповідь на пошкодження мозку при геморагічному інсульті та ВПГ-І. Методи. Проведено експерименти на 110 білих мишах Balb/c масою 18-20 г. Тварин інфікували ВПГ-I, на 30 добу моделювали геморагічний інсульт і визначали зміни 
астроцитів методом імуногістохімії. Гліоз визначали за щільністю та арборизацією відростків GFAPпозитивних астроцитів. Результати. Результати імуногістохімічного дослідження засвідчили збільшення щільності GFAP-позитивних відростків астроцитів у гіпокампу мишей інфікованих ВПГ-І, а після моделювання інсульту у інфікованих тварин різке збільшення щільності і гіпертрофію GFAP-позитивних астроцитів. Висновки. В експерименті отримано нові дані щодо локалізації та рівня астроцитарного гліозу при інсульті та герпетичній інфекції. GFAP можна розглядати як маркер реактивації ВПГ-І на тлі інсульту.

Кл юч о в і с л о в а: GFAP, астроцити, ВПГ-I, інсульт

\section{GFAP как показатель реактивных изменений} астроцитов в мозге мышей с геморрагическим инсультом и ВПГ-І
А. В. Гуменюк, С. Л. Рыбалко, С. И. Савосько, М. М. Гузик, А. А. Тихомиров, А. А. Рыжая, Ю. Б. Чайковский

Цель. исследовать изменения GFAP-позитивных астроцитов как проявление их реактивных изменений в ответ на повреждение мозга при геморрагическом инсульте и ВПГ-І. Методы. Проведены эксперименты на 110 белых мышах Balb/c массой 18-20 г. Животных инфицировали ВПГ-I, на 30 сутки моделировали геморрагический инсульт и определяли изменения астроцитов методом иммуногистохимии. Глиоз определяли по плотности и арборизации отростков GFAPпозитивных астроцитов. Результаты. Результаты иммуногистохимического исследования показали увеличение плотности GFAP-позитивных отростков астроцитов в гиппокампе мышей инфицированных ВПГ-I, а после моделирования инсульта у инфицированных животных резкое увеличение плотности и гипертрофию GFAP-позитивных астроцитов. Выводы. В эксперименте получены новые данные по локализации и уровню астроцитарного глиоза при инсульте и герпетической инфекции. GFAP можно рассматривать как маркер реактивации ВПГ-І на фоне инсульта.

Кл юч е в ы е с л о в а: GFAP, астроциты, ВПГ-I, инсульт 